\title{
Gas Phase Noncovalent Protein Complexes that Retain Solution Binding Properties: Binding of Xylobiose Inhibitors to the $\beta-1,4$ Exoglucanase from Cellulomonas fimi
}

\author{
Milica Tešić, Jacqueline Wicki, David K. Y. Poon, Stephen G. Withers, \\ and Donald J. Douglas \\ Department of Chemistry, University of British Columbia, Vancouver, British Columbia, Canada
}

\begin{abstract}
Tandem mass spectrometry has been used to compare gas-phase and solution binding of three small-molecule inhibitors to the wild type and three mutant forms of the catalytic domain of Cex, an enzyme that hydrolyses xylan and xylo-oligosaccharides. The inhibitors, xylobiosyldeoxynojirimycin, xylobiosyl-isofagomine lactam, and xylobiosyl-isofagomine consist of a common distal xylose linked to different proximal aza-sugars. The three mutant forms of the enzyme contain the substitutions Asn44Ala, Gln87Met, and Gln87Tyr that alter the binding interactions between Cex and the distal sugar of each inhibitor. An electrospray ionization (ESI) triple quadrupole MS/MS system is used to measure the internal energies, $\Delta E_{\text {int }}$, that must be added to gas-phase ions to cause dissociation of the noncovalent enzyme-inhibitor complexes. Collision cross sections of ions of the apo-enzyme and enzyme-inhibitor complexes, which are required for the calculations of $\Delta E_{\text {int }}$, have also been measured. The results show that, in the gas phase, enzyme-inhibitor complexes have more compact, folded conformations than the corresponding apo-enzyme ions. With the mutant enzymes, the effects of substituting a single residue can be detected. The energies required to dissociate the gas-phase complexes follow the same trend as the values of $\Delta G^{0}$ for dissociation of the complexes in solution. This trend is observed both with different inhibitors, which probe binding to the proximal sugar, and with mutants of Cex, which probe binding to the distal sugar. Thus the gas-phase complexes appear to retain much of their solution binding characteristics. (J Am Soc Mass Spectrom 2007, 18, 64-73) (c) 2007 American Society for Mass Spectrometry
\end{abstract}

$\mathrm{T}$ The discovery that electrospray ionization (ESI) can produce gas-phase ions of noncovalently bound solution complexes [1-3] led to the question of how the binding in the gas-phase complexes compares with the initial solution binding [4, 5]. Many of the noncovalent complexes reported to date involve proteins. Because the gas-phase ions are completely free of solvent, the ensemble of conformations adopted by a gas-phase protein may differ from that of the same protein in solution [6] leading to differences in the structural and energetic bases for protein-ligand interactions. In some cases, water molecules are directly involved in the solution binding interactions [7] and, therefore, in a gas-phase complex free of water, additional differences in binding may occur. Nevertheless, there have been several reports of complexes that retain at least some of their solution binding characteristics [8-17].

Published online September 26, 2006

Address reprint requests to D. J. Douglas, Department of Chemistry, University of British Columbia, 2036 Main Mall, Vancouver, BC, V6T 1Z1,

Canada. E-mail: douglas@chem.ubc.ca
An experimentally tractable method to investigate the details of binding in gas-phase complexes is to make systematic changes to the binding partners. This method has been used to investigate the effects of individual hydrogen bonds between heme and myoglobin and cytochrome $b_{5}$ [8], binding in double stranded DNA $[9,10]$, and to investigate binding of inhibitors to aldose reductase [11], peptides to vancomycin [12], and avoparcin [13], small molecules to carbonic anhydrase [14], peptides to OppA [15], an antibody single chain fragment to a series of structurally related trisaccharides $[7,16]$, and a series of trisaccharides to an antibody single chain fragment [17].

In this study, tandem mass spectrometry is used to compare, in detail, the binding energetics of noncovalent complexes of the catalytic domain of the wild type (WT) and three mutant forms (Asn44Ala, Gln87Met, and Gln87Tyr) of the catalytic domain of the $\beta-1,4$ glucanase Cex, with three small-molecule inhibitors in solution and in the gas phase. Cex is a family 10 glycosyl hydrolase, found in the microorganism Cellulomonas fimi. It catalyzes the hydrolytic cleavage of $\beta-1,4$ - linked polymers of xylose [18]. Five high-affinity 
Table 1. Inhibition constants, $\mathrm{K}_{\mathrm{i}}$, at $\mathrm{pH} 7$ and $37^{\circ} \mathrm{C}$ in $10 \mu \mathrm{M}$ ammonium acetate

\begin{tabular}{lccl}
\hline & \multicolumn{3}{c}{$K_{i}(\mu \mathrm{M})$} \\
\cline { 2 - 4 } & $\mathrm{X}_{2}$ DNJ & $\mathrm{X}_{2} \mathrm{IL}$ & $\mathrm{X}_{2} \mathrm{IF}$ \\
\hline \hline WT* $^{*}$ & 5.8 & 0.34 & 0.13 \\
GIn87Met & 18 & 2.1 & 0.39 \\
GIn87Tyr & 62 & 11 & 1.2 \\
Asn44Ala & 180 & 24 & 7.1 \\
\hline
\end{tabular}

*Values of $K_{i}$ for the WT protein are from [19a]; for the mutants, [19b].

xylobiose-derived aza-sugars that inhibit the catalytic activity of Cex have been described: imidazole, lactam oxime, deoxynojirimycin, isofagomine lactam, and isofagomine [19]. These were designed as possible transition-state analogues and all exhibit competitive inhibition, binding noncovalently at the active site. Threedimensional structures of complexes of each inhibitor with Cex have been determined [20].

Solution binding affinities have been determined as inhibition constants, $K_{i}$, which represent dissociation constants for the following equilibrium [19]:

$$
E+I \rightleftarrows E I
$$

with inhibition constant

$$
K_{i}=\frac{[E][I]}{[E I]}
$$

where $E$ represents the enzyme, I represents an inhibitor and EI the complex. Values of $K_{i}$ for the complexes studied here are shown in Table 1 . Figure 1 shows the structures of the three inhibitors used here, with binding affinity increasing in the order xylobiosyl-deoxynojirimycin $\left(\mathrm{X}_{2} \mathrm{DNJ}\right)$, xylobiosyl-isofagomine lactam $\left(\mathrm{X}_{2} \mathrm{IL}\right)$, and xylobiosyl-isofagomine $\left(\mathrm{X}_{2} \mathrm{IF}\right)$. All inhibitors consist of two sugars: a common distal xylose which binds to the -2 sub-site of Cex, and a distinct proximal aza-sugar which binds to the -1 sub-site $[18,20]$. Cex binds to the proximal and distal sugars through van der Waals interactions, electrostatic interactions, and a series of hydrogen bonds to amino acid side chains. Changes in the inhibitor structures probe binding of a given form of Cex to the proximal sugar. The mutant proteins used here probe binding to the distal xylose.

The X-ray crystal structures of the complexes provide insights into details of binding of the complexes $[19,20]$. Figure 2 shows, for example, the interactions between the active site of WT Cex and $X_{2}$ DNJ [20]. In comparison, when WT Cex binds $X_{2}$ IF [20], the interactions with the distal xylose are largely preserved, although the hydrogen bonds may have different lengths. With the proximal sugar, only the bond between His 80 and $\mathrm{OH}-3$ is preserved, but with a different length. Two new bonds are formed with the "anomeric" nitrogen N-1: one with the nucleophile Glu233 and a second with
Gln203. When WT Cex binds $\mathrm{X}_{2}$ IL [19a, 19b] instead of $\mathrm{X}_{2} \mathrm{DNJ}$, again the hydrogen bonds with the distal xylose are largely preserved. At the proximal sugar, only the interaction between His80 and $\mathrm{OH}-3$ is preserved. There are new interactions of O-2 with His80, Asn126, and the catalytic nucleophile Glu233, and of nitrogen N-1 with the acid-base catalyst Glu127 and the catalytic nucleophile Gln203.

Based upon the crystal structures of WT Cex with each of the inhibitors [20], as well as structures of some of these mutants with other inhibitors [21], it is possible to predict the consequences of these mutations upon ligand binding. In general, the interactions with the proximal sugar will be preserved as they are in WT Cex [21]. With the Asn44Ala mutant, the interaction between Asn 44 and OH-5 of the distal xylose is eliminated for all three inhibitors. Likewise, with the Gln87Met mutant, the hydrogen bond between Gln87 and O-2 of the distal xylose is removed for all three inhibitors. However, with the Gln87Tyr mutant, while the bond between $\mathrm{Gln} 87$ and O-2 of the distal xylose is removed, a new bond is formed with $\mathrm{OH}-4$.

Tandem mass spectrometry was used to determine the internal energies, $\Delta E_{\text {int }}$, that must be added to gas-phase ions of the complexes to cause dissociation. Collision cross sections, which are required to calculate $\Delta E_{\text {int }}$, were measured by ion energy loss experiments. Different dissociation mechanisms are observed for different complexes. For wild type Cex, the complex with the strongest inhibitor, $\mathrm{X}_{2} \mathrm{IF}$, exhibits only neutral
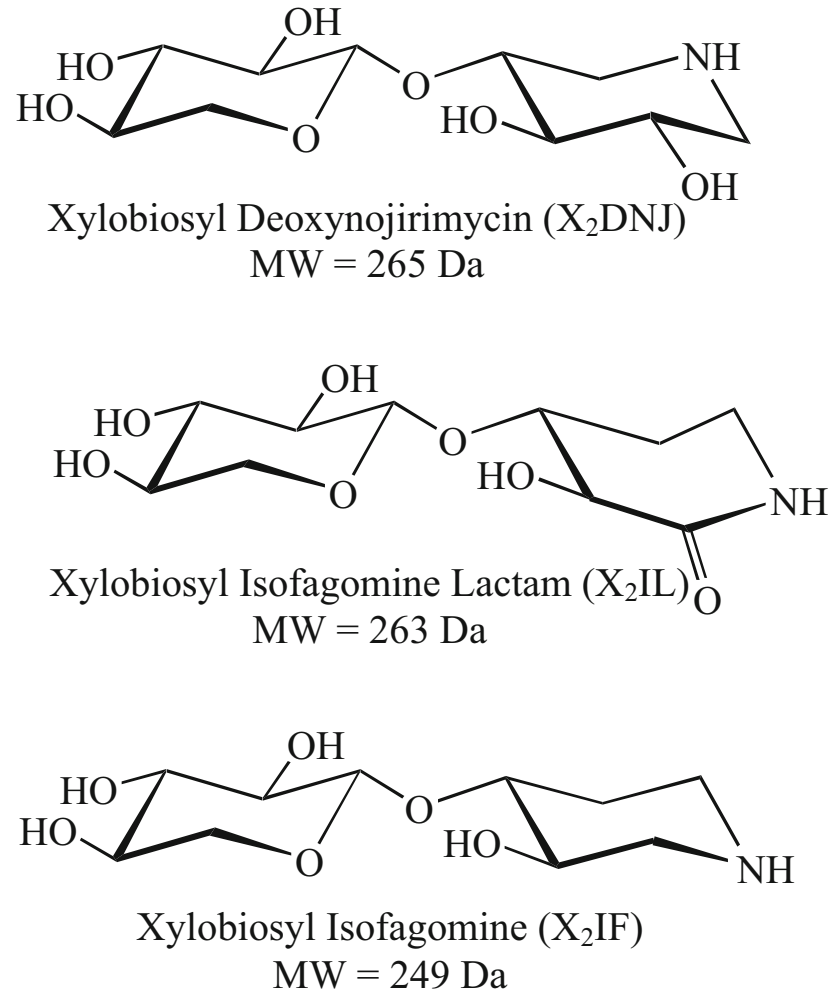

Figure 1. Structures of xylobiose-derived inhibitors of Cex. The distal xylose is on the left and the proximal sugar is on the right. 


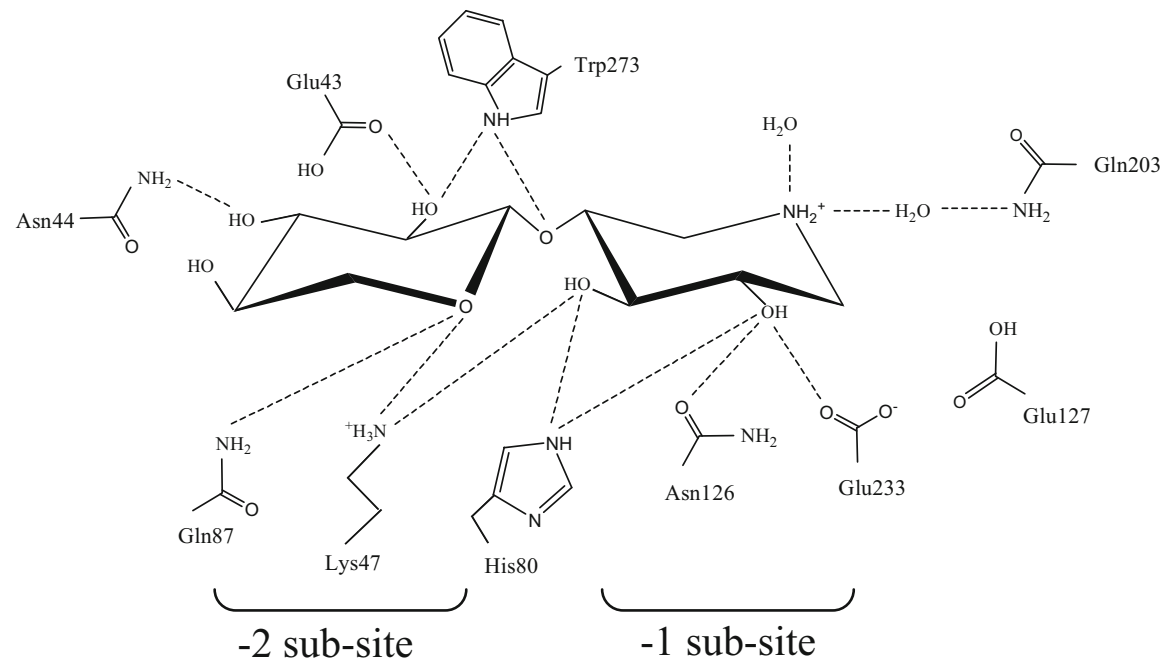

Figure 2. Interaction map showing the binding between the active site of wild type Cex and the proximal sugar and distal xylose of $\mathrm{X}_{2} \mathrm{DNJ}$ ( PDB Code:1FH7).

inhibitor loss, while the complexes with the weaker inhibitors $\mathrm{X}_{2} \mathrm{DNJ}$ and $\mathrm{X}_{2} \mathrm{IL}$ show both neutral and some $(<20 \%)$ charged inhibitor loss. The ratio of charged-toneutral inhibitor loss is largely independent of collision energy. All mutant proteins showed only neutral inhibitor losses. In the gas-phase ions, binding of the inhibitors appears to contribute significantly to stabilization of the protein fold, since complexes that are more strongly bound have lower collision cross sections. Values of $\Delta E_{\text {int }}$ were compared with $\Delta G^{0}$ for dissociation in solution. The results show that the complexes that are more strongly bound in solution require higher internal energies to cause dissociation in the gas phase. This trend was observed both with different inhibitors and with the mutant proteins. Thus binding of the enzyme to both the proximal and distal sugars in the gas phase seems to retain many of its solution properties.

\section{Experimental}

\section{Protein Expression and Purification}

All experiments used the catalytic domain of Cex and its mutants, expressed and purified according to methods ${ }^{\circ}$ adapted ${ }^{9}$ rom $^{\circ}$ earlier ${ }^{\circ}$ procedures $\left.921-23\right]$. Details ${ }^{\circ}$ are given in the Appendix. The final stock solution concentrations of all the proteins were about $1-4 \mathrm{mg} / \mathrm{mL}$.

\section{Reagents and Materials}

Solutions of purified Cex or its mutants were $10 \mu \mathrm{M}$. Solutions of the complexes were prepared simply by mixing the enzyme and the inhibitors in ratios calculated to produce nearly fully complexed enzyme in solution, e.g., for the WT- $\mathrm{X}_{2} \mathrm{DNJ}$ complex, $17 \mu \mathrm{L}$ of a 2.4 $\mathrm{mg} / \mathrm{mL}(69 \mu \mathrm{M})$ stock solution of WT-Cex was mixed with $2 \mu \mathrm{L}$ of a $4.0 \mathrm{mM}$ stock solution of $\mathrm{X}_{2} \mathrm{DNJ}$ in a total volume of $240 \mu \mathrm{L}$. The resulting equilibrium concentrations of the enzyme, inhibitor, and complex, calculated from the $K_{i}$ value, are about 1,29 , and $4 \mu \mathrm{M}$, respectively. Solutions contained $10 \%$ methanol (HPLC grade, Fisher Scientific, Fair Lawn, NJ), and $10 \mathrm{mM}$ ammonium acetate (Fisher Scientific) buffer, to minimize $\mathrm{pH}$ changes in electrospray. The addition of $10 \%$ alcohol to a protein solution does not generally lead to conformation changes, unless the protein is otherwise near to a folding ${ }^{\circ}$ transition $[24]$. Solution ${ }^{\circ} \mathrm{pH}^{\circ}$ was ${ }^{\circ}$ measured ${ }^{\circ}$ with an Accumet $\mathrm{pH}$ meter (Fisher Scientific, model 15). Solutions of the complexes with mutants were prepared in the same manner.

\section{Mass Spectrometry}

Experiments were performed with an ESI-triple quadrupole mass spectrometer system, described previously $\left[8,{ }^{\circ} 25,{ }^{\circ} 26\right] .^{\circ}{ }^{\circ}$ The $^{\circ}$ sprayer $^{\circ}$ consisted ${ }^{\circ}$ of a $2 \mathrm{~cm}$ length ${ }^{\circ}$ of fused silica capillary (Polymicro Technologies, Phoenix, AZ), with i.d. and o.d. of 76 and $150 \mu \mathrm{m}$, respectively, connected to a $3 \mathrm{~cm}$ long stainless steel tube (Small Parts Inc., Miami Lakes, FL) with i.d. and o.d. of 0.02 and 0.04 $\mathrm{cm}$. Samples were infused to the stainless steel tube at 1 $\mu \mathrm{L} / \mathrm{min}$. High voltage $(4000 \mathrm{~V})$ was applied to the stainless steel tube. Ions pass through a nitrogen curtain gas (manufacturer's stated purity $99.999 \%$, Praxair, Mississauga, Ontario, Canada), a $0.25 \mathrm{~mm}$-diameter sampling orifice into a region with a background pressure of 1.3 torr, then through a skimmer with a $0.75 \mathrm{~mm}$ diameter orifice, into an RF only quadrupole ion guide, $\mathrm{Q} 0$, operated at $4 \times 10^{-3}$ torr. Ions then pass into the main chamber containing quadrupoles Q1, Q2, and Q3 (background pressure $8 \times 10^{-6}$ torr). Ion counting was used for detection.

The potential difference between the orifice and the skimmer was $100 \mathrm{~V}$ in all experiments. The curtain plate 
was held at $1400 \mathrm{~V}$. The voltages on the lenses between the quadrupoles, Q0/Q1, Q1/Q2, Q2/Q3, and on the short RF only rods before Q1 were 100, 103, 85, $103 \mathrm{~V}$, respectively. The aperture at the exit of Q3 was $0 \mathrm{~V}$. For MS experiments the rod offsets on the quadrupoles Q0, Q1, Q2 and Q3 were 119, 110, 100 and $90 \mathrm{~V}$, respectively. For MS/MS experiments, the Q2 and Q3 rod offsets were varied, as described below. The frequency of the quadrupole RF was $0.768 \mathrm{MHz}$, giving a mass range of up to $m / z=6500$ (quadrupole field radius, 4.16 $\mathrm{mm})$. In all experiments, the collision gas was argon (Praxair, manufacturer's stated purity 99.9995\%). The pressure in the collision cell (length $20.6 \mathrm{~cm}$ ) was varied in the experiments and monitored by a capacitance manometer (MKS Instruments, Baratron model 120AA, Boulder, CO). All experiments were repeated four times. Uncertainties are the standard deviations of four repeated experiments.

\section{Collision Cross Section Measurements}

Ions are collisionally cooled to kinetic energy spreads of

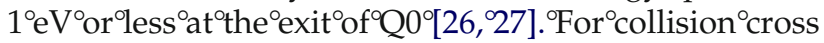
section experiments, Q1 was operated as an ion guide in RF only mode. Kinetic energies of ions leaving Q2 after collisions with argon were determined by increasing the rod offset voltage of Q3 until the ion signal was decreased by several orders of magnitude, to generate stopping curves. The pressure of the collision gas was varied and stopping curves were obtained for each pressure. ${ }^{\circ}$ An ${ }^{\circ}$ aerodynamic ${ }^{\circ} \mathrm{drag}^{\circ} \operatorname{model}{ }^{\circ}[26]^{\circ}{ }^{\text {was }}{ }^{\circ}$ used ${ }^{\circ}$ to calculate the protein cross sections from

$$
\frac{E}{E^{0}}=\exp \left(-\frac{C_{D} n m_{2} \sigma l}{m_{1}}\right) \circ
$$

where $E^{0}$ is the energy of an ion at the cell entrance, $E$ is the energy of an ion at the cell exit, $C_{D}$ is a drag coefficient, $n$ is the gas number density in the cell, $\sigma$ is the collision cross section, $l$ is the cell length, $m_{1}$ is the ion mass, and $m_{2}$ is the collision gas mass. Energies $E$ were taken as the energy at which the ion intensity was decreased ${ }^{\circ}$ to $^{\circ}$ one $^{\circ}$ tenth $^{\circ}$ of $^{\circ}$ the $^{\circ}$ initial $^{\circ}$ value $^{\circ}$ for ${ }^{\circ}$ each pressure. The collision cross section for each charge state was determined by plotting $-\ln \frac{E}{E^{0}}$ versus $\frac{C_{D} n m_{2} l}{m_{1}}$. Drag $^{\circ}$ coefficients $^{\circ}$ for $^{\circ}$ diffuse $^{\circ}$ scattering $^{\circ}$ were $^{\circ}$ used $^{\circ}\left[26\right.$. $^{\circ}$

\section{Tandem Mass Spectrometry}

In MS/MS experiments, the internal energy that must be added to ions of the complexes to induce dissociation is determined. The ion of interest was mass selected in Q1 and injected into the collision cell, where multiple collisions with argon caused dissociation. Fragment ions were mass analyzed in Q3. The Q0-Q2 rod offset difference was systematically increased to determine the voltage difference required to cause complexes to dissociate. The Q3 rod offset was set equal to the Q2 rod offset. For most complexes, where there is only loss of a neutral inhibitor, the dissociation voltage is taken as the Q0-Q2 voltage difference giving a 50\% loss of the inhibitor from the complex. The internal energy added to cause dissociation, $\Delta E_{i n t}$ is calculated from

$$
\Delta E_{\mathrm{int}}=\Phi \frac{m_{2}}{M} E^{0} \frac{m_{1}}{m_{2}} \frac{1}{C_{D}}\left[1-e^{-\frac{C_{D} n m_{2} \sigma l}{m_{1}}}\right]
$$

where $\Phi$ is the average fraction of the centre of mass kinetic energy transferred to internal energy in a collision (taken as $\Phi=1.0$ ), $E^{0}$ is the initial kinetic energy at the entrance of the collision cell under conditions where there is a $50 \%$ fragment yield, $m_{1}$ is the complex ion mass, and $M=m_{1}+m_{2}$. This model corrects for the different numbers of collisions of ions that have different collision cross sections and also for the energy losses of $^{\circ}$ ions $^{\circ}$ as $^{\circ}$ they ${ }^{\circ}$ move $^{\circ}$ through $^{\circ}$ the $^{\circ}$ cell $^{\circ}[25]$.

Internal energies needed for dissociation were calculated for all complexes at different pressures of the collision gas, ranging from 0.5 to 2.74 mTorr. The times available ${ }^{\circ}$ for ${ }^{\circ}$ eaction ${ }^{9} o^{\circ}$ occur $^{\circ}$ were $^{\circ}$ calculated ${ }^{\circ}$ as in [25], since the internal energies needed to induce dissociation, are best compared for equal reaction times. The added internal energies, $\Delta E_{\text {int }}$, which cause $50 \%$ dissociation in $25 \mu$ s are reported below.

\section{Results and Discussion}

\section{Mass Spectra}

The production of the catalytic domain of Cex involves the in vivo post-translational removal of the Cex Nterminal leader peptide, as well as the in vitro cleavage and removal of a C-terminal linker and cellulosebinding region. In comparison with the published sequence from which the crystal structure was derived [28], the $^{\circ}$ catalytic $^{\circ}$ domain $^{\circ}$ of $^{\circ} \mathrm{Cex}^{\circ}$ produced ${ }^{\circ}$ and ${ }^{\circ}$ used ${ }^{\circ}$ for these experiments contains the additional amino acids GAS at the C-terminus, and contains the residues VVLPAQA at the N-terminus to give a calculated molecular weight of $34,849 \mathrm{Da}$. The mass spectrum of denatured Cex gave a mass of $34,866 \pm 44 \mathrm{Da}$ in reasonable agreement with the calculated mass.

The optimum $\mathrm{pH}$ range for the catalytic activity of xylanases is typically 4 to 7929 ]. Figure $3 a^{\circ}$ shows ${ }^{\circ}$ amass spectrum ${ }^{\circ}$ of $^{\circ} a^{\circ}$ solution ${ }^{\circ}$ of ${ }^{\circ}$ wild-type ${ }^{\circ} \mathrm{Cex}^{\circ}(\mathrm{WT})^{\circ}$ and ${ }^{\circ} \mathrm{X}_{2} \mathrm{IF}$ at pH 5.8. Peaks from enzyme (E) and complex (EI) are seen. A narrow distribution of charge states from +9 to +12 , with +10 being the most intense, is formed as expected ${ }^{\circ}$ for $^{\circ}$ the ${ }^{\circ}$ protein ${ }^{\circ}$ in $^{\circ}$ its $^{\circ}$ native ${ }^{\circ}$ conformation $^{\circ}[25$, 30]. ${ }^{\circ}$ The $^{\circ}$ peaks $^{\circ}$ of $^{\circ}$ the ${ }^{\circ} \operatorname{complex}^{\circ}(\mathrm{EI})^{\circ}$ are $^{\circ} 30^{\circ}$ to $^{\circ} 40 \%{ }^{\circ}$ as intense as those of the enzyme (E) for the same charge state, even though, from the solution $K_{i}$, it is calculated

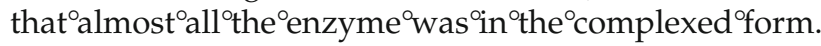
The gas-phase abundances do not reflect the solution 

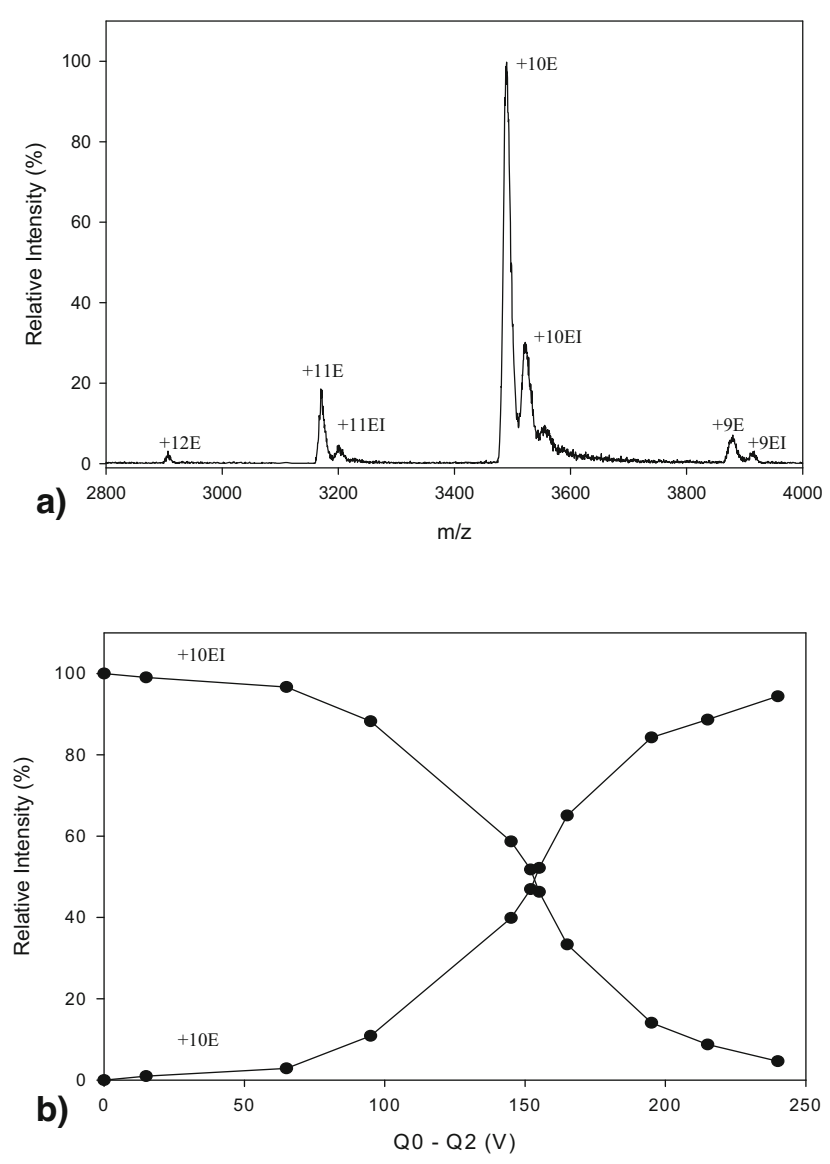

Figure 3. (a) Mass spectrum of a solution of wild type Cex with $\mathrm{X}_{2} \mathrm{IF}$ in $10 / 90 \%$ methanol/water at $\mathrm{pH}$ 5.8. Calculated solution concentrations $[\mathrm{EI}] \approx 4.9 \mu \mathrm{M},[\mathrm{E}] \approx 0.01 \mu \mathrm{M}$. $(\mathrm{b})$ Relative abundances of $\mathrm{EI}^{+10}$ and $\mathrm{E}^{+10}$ ions in MS/MS spectra of WT- $\mathrm{X}_{2} \mathrm{IF}$ ions versus Q0-Q2 rod offset voltage difference at a collision cell pressure of 1.5 mTorr of Ar.

equilibria. The lower abundance of ions of the complex may be the result of the addition of $10 \%$ methanol to the solution, some dissociation of the complex in the orificeskimmer region, or a shift to lower $\mathrm{pH}$ during the spray process. A small third peak for each charge state appears in the spectrum corresponding to the mass of $\mathrm{E}+$ 2I. Since neither Cex nor its mutants have more than one binding site, this peak is attributed to non-specific binding.

With all the forms of Cex, spectra showed narrow charge state distributions with charges +9 to +12 . Spectra of the complexes with $\mathrm{X}_{2} \mathrm{DNJ}$ and $\mathrm{X}_{2} \mathrm{IL}$ always had +11 as the most intense peak, while in the spectra of the complexes with $X_{2} I F$, the most intense was +10 . Spectra of the mutants were slightly shifted in mass compared to the WT, corresponding to the difference in mass of the native and altered amino acid residues. The charge states of the complexes with mutants were the same as of the WT for a given inhibitor, suggesting that the charge state distribution depends somewhat on the inhibitor.

\section{Collision Cross Sections}

Collision cross sections were measured for $\mathrm{E}$ and EI ions from solutions of all the complexes, and for the $\mathrm{E}$ ions

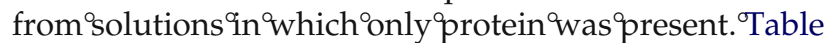
$2^{\circ}$ lists $^{\circ}$ all ${ }^{\circ}$ the ${ }^{\circ}$ cross $^{\circ}$ sections $^{\circ}$ obtained. ${ }^{\circ}$ Uncertainties ${ }^{\circ}$ are standard deviations of four replicate measurements. There is a small increase in the cross sections with the charge state of the ions, although in some cases this increase is less than the combined uncertainties in the cross sections. This is likely the result of Coulomb repulsion within the ions, causing them to unfold. Free protein $^{\circ}$ ions $^{\circ}$ formed $^{\circ}$ from ${ }^{\circ}$ solutions ${ }^{\circ}$ in $^{\circ}$ which ${ }^{\circ}$ only enzyme is present have slightly, but consistently, higher cross sections for a given charge than free protein ions from solutions of the complexes of the same protein, and this difference is most significant for the WT. Possibly in the presence of the solution complex, some protein ions are formed by dissociation of the complex in the orifice-skimmer region. If protein ions retain the same conformation as in the complex on the time scale of the experiment, they may retain more compact configurations. Ions of the complexes may be dissociated in the orifice-skimmer region by energetic collisions that "heat" the complexes. If energy that would otherwise cause the protein ions to unfold somewhat is used to dissociate the complexes, less energy is available to cause the protein ions to unfold, leaving them with slightly more compact structures. Ions of the complexes consistently have slightly lower cross sections than protein ions of the same charge formed from solutions of protein only, suggesting that binding the inhibitors helps to stabilize the protein in more compact structures. This is discussed further below.

\section{Tandem Mass Spectra}

Most complexes were found to dissociate simply via loss of a neutral inhibitor. As the collision energy is increased, the intensity of the $E I^{+n}$ peak in the MS/MS spectrum decreases, accompanied by an increase in the intensity of the $E^{+n}$ peak. Relative intensities of the precursor (complex) and fragment (enzyme) ions were calculated from:

$$
I_{i}(\%)=\frac{I_{i}}{I_{\text {precursor }}+I_{\text {fragment }}} \cdot 100 \%
$$

where $I_{\text {precursor }}$ is the intensity of the precursor, $I_{\text {fragment }}$ is the intensity of a fragment (complex minus neutral inhibitor) and $i=$ precursor or fragment. Dissociation curves, plots of relative intensities of precursor $\left(E I^{+10}\right)$ and fragment $\left(E^{+10}\right)$ ions versus the $\mathrm{Q} 0-\mathrm{Q} 2$ voltage difference, for the +10 charge state of the complex WT- $\mathrm{X}_{2} \mathrm{IF}$ at a cell pressure of $1.5 \mathrm{mTorr}$, are shown in Figure $^{\circ} 3 \mathrm{~b}^{\circ}{ }^{\circ}$ Similar $^{\circ}$ curves $^{\circ}$ were $^{\circ}$ obtained $^{\circ}$ for $^{\circ}$ all $^{\circ}$ the complexes with mutant proteins.

The two complexes, WT- $\mathrm{X}_{2} \mathrm{DNJ}$ and $\mathrm{WT}-\mathrm{X}_{2} \mathrm{IL}$, showed different behavior, with small amounts $(<20 \%)$ 
Table 2.

(a) Collision Cross Sections $\left(\AA^{2}\right)$ of wild type Cex and WT complexes

\begin{tabular}{|c|c|c|c|c|c|c|c|}
\hline \multirow[b]{2}{*}{ Charge } & \multirow{2}{*}{$\frac{\text { WT }}{\mathrm{E}}$} & \multicolumn{2}{|c|}{ WT- $\mathrm{X}_{2} \mathrm{DNJ}$} & \multicolumn{2}{|c|}{ WT-X $\mathrm{X}_{2} \mathrm{IL}$} & \multicolumn{2}{|c|}{ WT-X $\mathrm{IF}$} \\
\hline & & $E$ & $\mathrm{El}$ & $E$ & $\mathrm{El}$ & $\mathrm{E}$ & $\mathrm{El}$ \\
\hline+9 & $1727 \pm 31$ & $1320 \pm 91$ & $1398 \pm 44$ & $1348 \pm 69$ & $1428 \pm 36$ & $1546 \pm 37$ & $1218 \pm 44$ \\
\hline+10 & $1790 \pm 49$ & $1362 \pm 61$ & $1378 \pm 15$ & $1444 \pm 10$ & $1448 \pm 29$ & $1636 \pm 55$ & $1257 \pm 26$ \\
\hline+11 & $1803 \pm 44$ & $1591 \pm 68$ & $1552 \pm 38$ & $1578 \pm 73$ & $1526 \pm 36$ & $1637 \pm 33$ & $1318 \pm 65$ \\
\hline
\end{tabular}

(b) Collision Cross Sections $\left(\AA^{2}\right)$ of GIn87Met Cex and GIn87Met complexes

\begin{tabular}{|c|c|c|c|c|c|c|c|}
\hline \multirow[b]{2}{*}{ Charge } & \multirow{2}{*}{$\frac{\text { GIn87Met }}{E}$} & \multicolumn{2}{|c|}{ GIn87Met $-\mathrm{X}_{2} \mathrm{DNJ}$} & \multicolumn{2}{|c|}{ GIn87Met $-\mathrm{X}_{2} \mathrm{IL}$} & \multicolumn{2}{|c|}{ GIn87Met $-X_{2} I F$} \\
\hline & & $E$ & $\mathrm{El}$ & E & $\mathrm{El}$ & E & $\mathrm{El}$ \\
\hline+9 & $1620 \pm 64$ & $1529 \pm 34$ & $1412 \pm 53$ & $1548 \pm 32$ & $1403 \pm 21$ & $1432 \pm 56$ & $1262 \pm 22$ \\
\hline+10 & $1720 \pm 72$ & $1548 \pm 56$ & $1486 \pm 48$ & $1590 \pm 36$ & $1526 \pm 46$ & $1476 \pm 28$ & $1354 \pm 46$ \\
\hline+11 & $1780 \pm 46$ & $1620 \pm 23$ & $1595 \pm 81$ & $1635 \pm 74$ & $1582 \pm 36$ & $1498 \pm 43$ & $1426 \pm 33$ \\
\hline
\end{tabular}

(c) Collision Cross Sections $\left(\AA^{2}\right)$ of Asn44Ala Cex and Asn44Ala complexes

\begin{tabular}{|c|c|c|c|c|c|c|c|}
\hline \multirow[b]{2}{*}{ Charge } & \multirow{2}{*}{$\frac{\text { Asn44Ala }}{\mathrm{E}}$} & \multicolumn{2}{|c|}{ Asn44Ala $-\mathrm{X}_{2} \mathrm{DNJ}$} & \multicolumn{2}{|c|}{ Asn44Ala $-\mathrm{X}_{2} \mathrm{IL}$} & \multicolumn{2}{|c|}{ Asn44Ala $-\mathrm{X}_{2} \mathrm{IF}$} \\
\hline & & $E$ & $\mathrm{EI}$ & $\mathrm{E}$ & $\mathrm{EI}$ & $\mathrm{E}$ & $\mathrm{El}$ \\
\hline+9 & $1605 \pm 44$ & $1591 \pm 32$ & $1581 \pm 22$ & $1598 \pm 33$ & $1518 \pm 18$ & $1522 \pm 72$ & $1422 \pm 44$ \\
\hline+10 & $1638 \pm 31$ & $1636 \pm 98$ & $1612 \pm 69$ & $1655 \pm 50$ & $1618 \pm 58$ & $1562 \pm 27$ & $1486 \pm 70$ \\
\hline+11 & $1730 \pm 12$ & $1701 \pm 33$ & $1685 \pm 74$ & $1699 \pm 39$ & $1605 \pm 46$ & $1582 \pm 43$ & $1482 \pm 62$ \\
\hline
\end{tabular}

(d) Collision Cross Sections $\left(\AA^{2}\right)$ of GIn87Tyr Cex and GIn87Tyr complexes

\begin{tabular}{|c|c|c|c|c|c|c|c|}
\hline \multirow[b]{2}{*}{ Charge } & \multirow{2}{*}{$\frac{\text { Gln87Tyr }}{E}$} & \multicolumn{2}{|c|}{ GIn87Tyr - $\mathrm{X}_{2} \mathrm{DNJ}$} & \multicolumn{2}{|c|}{ GIn87Tyr - $\mathrm{X}_{2} \mathrm{IL}$} & \multicolumn{2}{|c|}{ GIn87Tyr - $\mathrm{X}_{2} \mathrm{IF}$} \\
\hline & & $E$ & $\mathrm{EI}$ & $E$ & El & E & El \\
\hline+9 & $1642 \pm 46$ & $1573 \pm 32$ & $1562 \pm 36$ & $1554 \pm 33$ & $1554 \pm 87$ & $1465 \pm 85$ & $1437 \pm 48$ \\
\hline+10 & $1670 \pm 42$ & $1638 \pm 57$ & $1595 \pm 51$ & $1654 \pm 100$ & $1601 \pm 52$ & $1450 \pm 72$ & $1408 \pm 58$ \\
\hline+11 & $1762 \pm 50$ & $1630 \pm 43$ & $1606 \pm 51$ & $1722 \pm 83$ & $1599 \pm 44$ & $1518 \pm 44$ & $1475 \pm 49$ \\
\hline
\end{tabular}

of charged inhibitor loss. The ratio of charged-toneutral inhibitor loss was largely independent of collision energy, indicating that similar energies are required for dissociation by either channel. The data for these two complexes were analyzed in two ways. First, only the neutral loss channel was included, and the dissociation voltage was determined as above. Second, the sum of charged and neutral losses was plotted versus energy and the voltage where the $E I^{+n}$ intensity equalled the sum of $E^{+n}$ and $E^{+(n-1)}$ intensities was taken as the dissociation voltage. This second method produces dissociation voltages that are 2 to $11 \%$ lower than the first. Values of $\Delta E_{i n t}$ calculated from the second method are used here.

\section{Internal Energies}

Dissociation voltages were determined for the +10 and +11 charge states of all the complexes at collision cell pressures ranging from 0.50 to 2.74 mTorr. At lower pressures, higher dissociation voltages are required for dissociation because ions have fewer collisions and therefore more energy per collision is required. Energy losses of ions moving through the cell must be considered and losses are lower at lower pressures. In addition, at lower pressures, ions travel faster through the cell, have less time available for reaction, and therefore need more internal energy to give a 50\% fragmentation yield than at higher pressures.

Under conditions that give $50 \%$ fragment yield, the reaction ${ }^{\circ}$ cccurs $^{\circ}$ over $^{\circ}$ a length, $l^{\prime},{ }^{\prime}$ of ${ }^{\circ}$ about ${ }^{\circ} 5^{\circ} \mathrm{cm}^{\circ}$ near ${ }^{\circ}$ the cell ${ }^{\circ}$ exit, $^{\circ}$ about $^{\circ} 18^{\circ} \mathrm{cm}^{\circ}$ from ${ }^{\circ}$ the ${ }^{\circ}$ entrance $^{\circ}[25] .{ }^{\circ}$ The $^{\circ}$ ion energy and hence the ion speed in this region can be calculated from the translational energy using eq 3 with $l=18 \mathrm{~cm}$. This gives the expression for the reaction time as follows:

$$
t=\frac{l^{\prime}}{\left(\frac{2 E^{0}}{m_{1}} \exp \left(-\frac{C_{D} n m_{2} l \sigma}{m_{1}}\right)\right)^{1 / 2}}
$$

with ${ }^{\circ}{ }^{\prime}={ }^{\circ} 5^{\circ} \mathrm{cm}$.

Figure 4 shows ${ }^{\circ}$ a plot ${ }^{\circ}$ of $\Delta E_{\text {int }}$ versus reaction time for complexes of WT Cex. It can be seen that within the uncertainties, similar energies are required to dissociate 


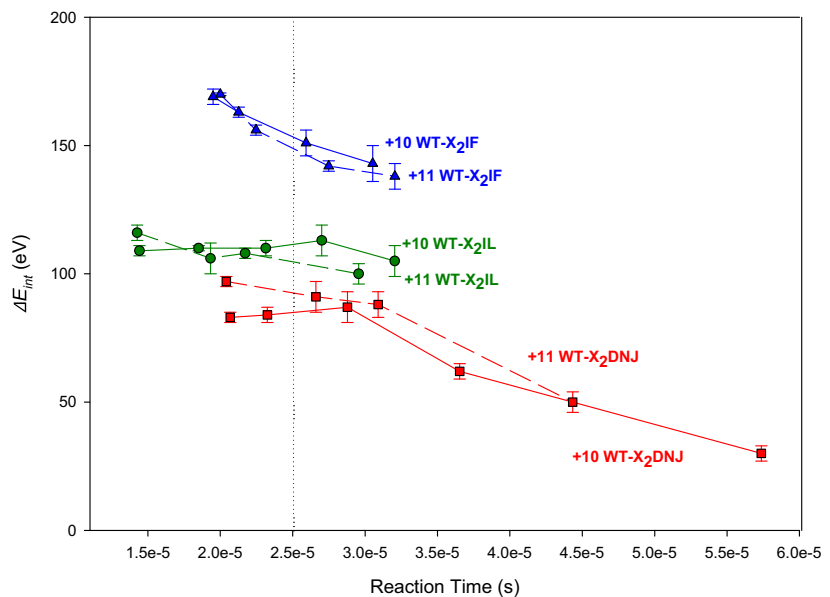

Figure 4. Added internal energies to cause dissociation, $\Delta E_{\text {int }}$ versus the time available for reaction for the +10 and +11 charge states of complexes of wild type Cex with three inhibitors: $\mathrm{X}_{2} \mathrm{DNJ}$, $\mathrm{X}_{2} \mathrm{IL}$, and $\mathrm{X}_{2} \mathrm{IF}$.

the +10 and +11 charge states for each complex. The values of $\Delta E_{\text {int }}$ for a given reaction time follow the order $\mathrm{WT}-\mathrm{X}_{2} \mathrm{IF}>\mathrm{WT}-\mathrm{X}_{2} \mathrm{IL}>\mathrm{WT}-\mathrm{X}_{2} \mathrm{DNJ}$.

The curves of $\Delta E_{\text {int }}$ versus reaction time for the complexes with mutants are similar to the curves for the complexes with WT. The mutants show the same trend as WT. The greatest internal energy is needed for the dissociation of complexes with $\mathrm{X}_{2} \mathrm{IF}$, and the lowest for complexes with $\mathrm{X}_{2} \mathrm{DNJ}$. The internal energies needed for the dissociation of all complexes with mutants are lower than for the corresponding complexes for WT. Among the mutants, Gln87Met requires the highest, Gln87Tyr less, and Asn44Ala the lowest energy for dissociation. Values of $\Delta E_{\text {int }}$ used below were taken from $^{\circ}$ plots $^{\circ}$ such $^{\circ}$ as $^{\circ}$ those ${ }^{\circ}$ in $^{\circ}$ Figure $^{\circ} 4^{\circ}$ for $^{\circ}$ equal ${ }^{\circ}$ reaction times of $25 \mu \mathrm{s}$. Values of $\Delta E_{\text {int }}$ for dissociation of +10

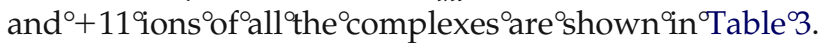
Also shown are values of the free-energy change for dissociation of the complexes in solution at $37^{\circ} \mathrm{C}$, $\Delta G^{0}$ dissociation, $^{\circ}$ calculated $^{\circ}$ from $^{\circ} \Delta G^{0}$ dissociation $=-k_{B} T \ln K_{i}$, where $k_{B}$ is Boltzmann's constant $\left(k_{B}=8.617 \times 10^{-5}\right.$ $\mathrm{eV} \mathrm{K}{ }^{-1}$ ).
The complexes with two bound inhibitors were not studied in detail. A preliminary experiment with +11 WT- $\mathrm{X}_{2} \mathrm{DNJ}_{2}$ ions showed that this complex dissociates by roughly equal losses of charged and neutral inhibitor. The internal energy required to reduce the precursor intensity to one half of its initial value was found to be $\Delta E_{\text {int }}=45 \mathrm{eV}(0.8 \mathrm{~m}$ Torr cell pressure, $30 \mu$ s reaction time). This energy is about one half of that required for dissociation of +11 WT- $\mathrm{X}_{2} \mathrm{DNJ}$ complex ions in about the $^{\circ}$ same $^{\circ}$ reaction $^{\circ}$ time $^{\circ}\left(95^{\circ} \mathrm{eV}^{\circ}, \mathrm{Table}^{\circ} 3,{ }^{\circ}\right.$ and $^{\circ}$ Figure $\left.^{\circ} 4\right)$, suggesting weaker binding of the non-specific complex. This $^{\circ}$ contrasts $^{\circ}$ to $^{\circ}$ the $^{\circ}$ findings ${ }^{\circ}$ of $^{\circ} \mathrm{Wang}^{\circ}$ et $^{\circ}$ al. $^{\circ}$ where non-specific binding was found to be stronger than specific binding in a ${ }^{\circ}$ protein-carbohydrate ${ }^{\circ}$ complex $[31]$.

\section{Collision Cross Sections and Gas Phase Binding}

The cross sections and $\Delta E_{\text {int }}$ values show that binding of inhibitors in the gas-phase complex causes the protein to ${ }^{\circ}$ adopt ${ }^{\circ}$ more $^{\circ}$ compact $^{\circ}$ conformations. $^{\circ}$ Figure ${ }^{\circ} 5 \mathrm{a}^{\circ}$ and $\mathrm{b}$ show ${ }^{\circ}$ cross $^{\circ}$ sections $^{\circ}$ for ${ }^{\circ}$ the ${ }^{\circ} \operatorname{complexes}^{\circ}$ versus ${ }^{\circ}$ the ${ }^{\circ} \Delta E_{\text {int }}$ values ${ }^{\circ}$ or ${ }^{\circ}$ dissociation ${ }^{\circ}$ of the $e^{\circ}$ complexes $^{\circ}$ for ${ }^{\circ}$ the ${ }^{\circ}+10^{\circ}$ and $+11^{\circ}$ ions $^{\circ}$ respectively. $^{\circ}$ Also $^{\circ}$ shown $^{\circ}$ in $^{\circ}$ Figure $^{\circ} 5,{ }^{\circ}$ by dashed lines, are the cross sections of the protein ions produced from solutions of protein only. All complexes have cross sections lower than those of the protein ions formed from solutions of protein only. The complexes and protein ions in these low charge states retain considerable folded structures; apo-protein ions with charge states +22 to +35 formed from Cex denatured in solution have considerably greater cross sections of 3300 to $4000 \AA^{2}$ (data not shown). There is a strong correlation between the cross sections and $\Delta E_{\text {int }}$ values, with the more strongly bound complexes having smaller ${ }^{\circ}$ rross $^{\circ}$ sections. The $e^{\circ}$ lines ${ }^{\circ}$ in ${ }^{\circ}$ Figure $^{\circ} 5^{\circ}$ are $^{\circ}$ secondorder ${ }^{\circ}$ fits $^{\circ}{ }^{\circ}$ simply $^{\circ}$ to ${ }^{\circ}$ illustrate ${ }^{\circ}$ the ${ }^{\circ}$ trend $^{\circ}$ Binding $^{\circ}$ the inhibitor apparently helps keep the protein folded, most likely around the binding pocket, with stronger binding giving more tightly folded conformations. A related

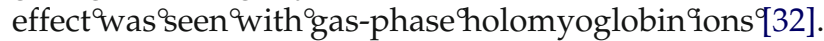

The change in average conformation with inhibitor binding is readily detected in the gas-phase ions. In

Table 3. Free energy changes for the dissociation of complexes in solution and internal energies required for the dissociation of gas phase complexes in $25 \mu \mathrm{s}$

\begin{tabular}{|c|c|c|c|}
\hline Complex & $\Delta G_{\text {dissociation }}^{0}(\mathrm{eV})$ & +10 ions $\Delta E_{i n t}(\mathrm{eV})$ & +11 ions $\Delta E_{i n t}(\mathrm{eV})$ \\
\hline WT-X ${ }_{2} \mathrm{DNJ}$ & 0.318 & $86 \pm 3$ & $95 \pm 3$ \\
\hline WT-X ${ }_{2} \mathrm{IL}$ & 0.393 & $113 \pm 6$ & $105 \pm 3$ \\
\hline WT-X ${ }_{2} I F$ & 0.419 & $154 \pm 5$ & $147 \pm 5$ \\
\hline GIn87Met- $\mathrm{X}_{2} \mathrm{DNJ}$ & 0.288 & $69 \pm 4$ & $79 \pm 4$ \\
\hline GIn87Met-X ${ }_{2} I L$ & 0.345 & $102 \pm 3$ & $92 \pm 2$ \\
\hline GIn87Met- $X_{2} I F$ & 0.390 & $131 \pm 3$ & $139 \pm 2$ \\
\hline GIn87Tyr-X 2 DNJ & 0.256 & $68 \pm 4$ & $53 \pm 2$ \\
\hline GIn87Tyr-X & 0.302 & $81 \pm 3$ & $73 \pm 4$ \\
\hline GIn87Tyr-X ${ }_{2} \mathrm{IF}$ & 0.360 & $122 \pm 4$ & $125 \pm 6$ \\
\hline Asn44Ala- $\mathrm{X}_{2} \mathrm{DNJ}$ & 0.228 & $45 \pm 3$ & $48 \pm 3$ \\
\hline Asn44Ala- $\mathrm{X}_{2} \mathrm{IL}$ & 0.281 & $53 \pm 4$ & $53 \pm 3$ \\
\hline Asn44Ala- $X_{2} I F$ & 0.313 & $95 \pm 4$ & $93 \pm 4$ \\
\hline
\end{tabular}



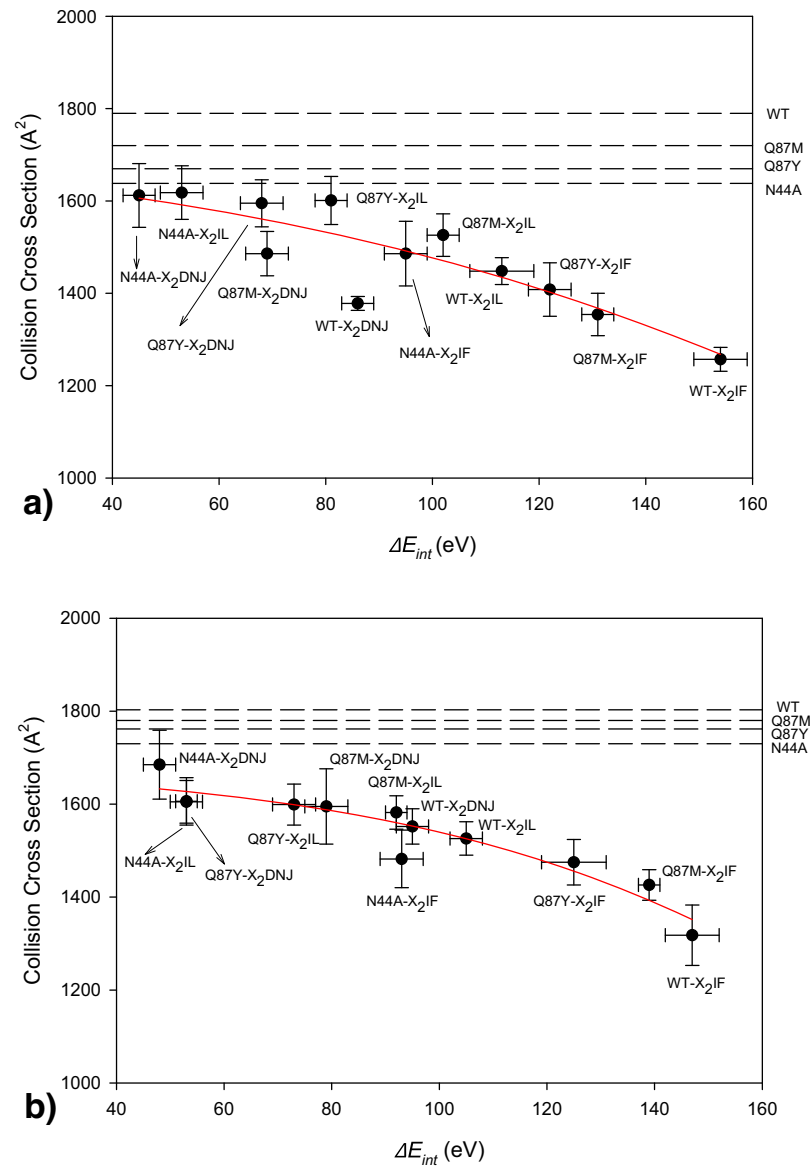

Figure 5. Collision cross sections of the complexes versus the added internal energy to cause dissociation, $\Delta E_{\text {int }}$, for (a) +10 ions and $(\mathbf{b})+11$ ions.

contrast, the crystal structures show no significant structural ${ }^{\circ}$ changes $^{\circ}$ of $^{\circ}$ the ${ }^{\circ}$ protein $^{\circ}$ upon ${ }^{\circ}$ binding $^{\circ}$ of ${ }^{\circ}$ the inhibitors ${ }^{\circ}\left[19,{ }^{\circ} 20\right] .{ }^{\circ}$ However ${ }^{\circ}$ proteolysis ${ }^{\circ}$ and ${ }^{\circ}$ thermal denaturation studies show that the formation of a covalent glycosyl-enzyme intermediate stabilizes Cex against ${ }^{\circ}$ unfolding $[33]$. These ${ }^{\circ}$ observations ${ }^{\circ}$ suggest ${ }^{\circ}$ that, rather than a distinct different conformation being stabilized, the range of conformational space occupied is reduced in the presence of the inhibitor.

\section{Comparisons of Solution and Gas Phase Binding}

Figure $^{\circ} 6^{\circ}$ shows $^{\circ}$ values $^{\circ}$ of ${ }^{\circ} \Delta E_{\text {int }}$ plotted against the values of $\Delta G^{0}$ for dissociation of the complexes in solution. In solution, the inhibition strength increases in the order: $\mathrm{X}_{2} \mathrm{DNJ}<\mathrm{X}_{2} \mathrm{IL}<\mathrm{X}_{2} \mathrm{IF}$ for all the proteins. As can $^{\circ} \mathrm{be}^{\circ}$ seen $^{\circ}{ }^{\circ}$ rom $^{\circ}{ }^{\circ}$ able $3^{\circ}$ and ${ }^{\circ}$ Figure $^{\circ} 6,{ }^{\circ}$ the ${ }^{\circ} \Delta E_{\text {int }}$ values for all the ions of the protein complexes follow the same trends.

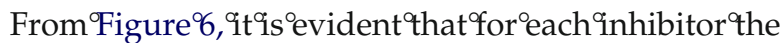
internal energy needed for dissociation in the gas phase increases ${ }^{\circ}{ }^{\circ}{ }^{\circ}$ the ${ }^{\circ}$ order $^{\circ}$ Asn44Ala $<$ Gln87Tyr $<$ Gln87Met $<\mathrm{WT}$, for both charge states, the same as the order of increase of $\Delta G^{0}$ for dissociation in solution. These same changes in binding are seen irrespective of the identity of the proximal aza-sugar. Thus, binding to the proximal sugar in the gas-phase complex appears to be similar to the binding in solution. Mutations that remove or alter individual hydrogen bonds to the distal xylose to reduce the solution binding strength, also reduce the energy required to cause dissociation in the gas-phase ions. Therefore individual hydrogen bonds involved in interactions with Gln87 and Asn44 in solution probably remain in the gas phase. Individual hydrogen bonds between heme and myoglobin were previously shown to persist in the gas-phase holoprotein $^{\circ}[8] .{ }^{\circ}$ Likely, $^{\circ}$ the ${ }^{\circ}$ solution $^{\circ}$ structures ${ }^{\circ}$ are $^{\circ}$ partially preserved in the gas phase in these protein smallmolecule complexes in part because inhibitor binding stabilizes the complex, holding the binding pocket together.

Kitova et al. reported activation energies for dissociation of trisaccharides from an antibody single chain fragment ${ }^{\circ}$ measured ${ }^{\circ}$ in $^{\circ}$ blackbody ${ }^{\circ}$ infrared ${ }^{\circ}$ dissociation (BIRD) ${ }^{\circ}$ experiments $[7]^{\circ},{ }^{\circ}{ }^{\circ}{ }^{\circ}$ found ${ }^{\circ}$ that ${ }^{\circ}$ activation ${ }^{\circ}$ energies did not correlate with $\Delta H^{0}$ for association of the
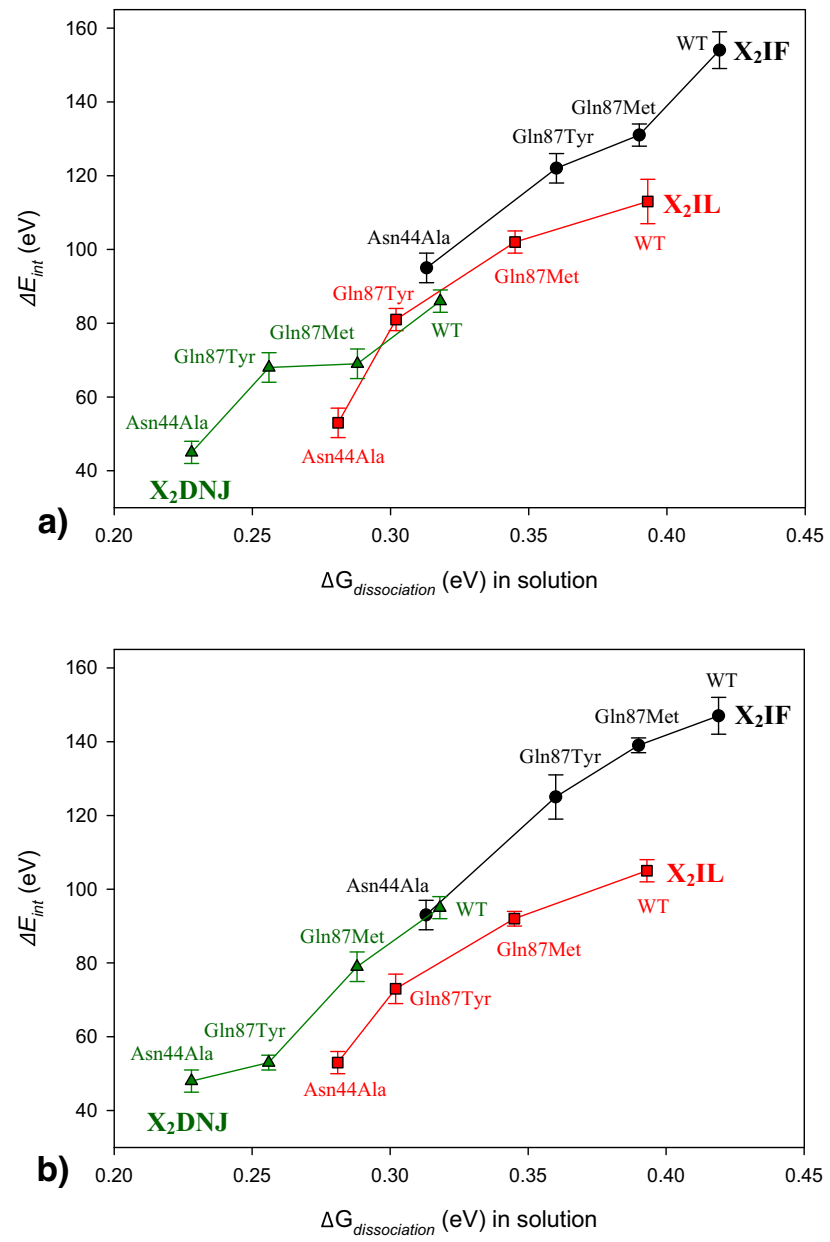

Figure 6. Internal energies needed for dissociation of ions of the complexes of WT, Gln87Met, Gln87Tyr, and Asn44Ala with inhibitors $X_{2} D N J, X_{2} I L$, and $X_{2} I F$ in the gas phase versus $\Delta G^{0}$ for dissociation of the complexes in solution for charges (a) +10 and (b) +11 . 
complexes in solution. This was attributed to structural differences between the solution and gas-phase proteins. If such differences exist in the Cex complexes, they do not alter the order of the binding energies in the gas phase. It is possible the difference in time scales between these tandem MS/MS experiments and the BIRD experiments contributes to these different results. Ions are formed and dissociate in tens of microseconds in the triple quadrupole experiments. In the BIRD experiments, the ions are trapped for times of a few to more than a hundred seconds. On this longer time scale the ions may undergo unfolding or refolding transitions to structures that differ markedly from the solution structures [34].

\section{Summary}

The results presented here represent a detailed study of binding in a gas-phase protein small-molecule complex. The correlation between cross section and dissociation energies suggests that binding of the small molecule helps stabilize the complex in the gas phase. Mutant versions of the protein can be used to probe the effects of removal of individual sets of interactions in the complex. The strong correlation between gas-phase dissociation energies and $\Delta G^{0}$ for dissociation in solution suggests that much of the solution binding pocket is retained in the gas-phase ion. The method used here, combining tandem mass spectrometry with systematic alterations to the binding partners, should be applicable to a broad range of noncovalent complexes.

\section{Acknowledgments}

This project is supported by the Natural Sciences and Engineering Research Council of Canada. The authors thank Dr. Spencer J. Williams for synthesis of the inhibitors.

\section{Appendix}

\section{Protein Production and Purification}

The plasmid, pUC12-1.1Cex(PTIS) [35] ${ }^{\circ} \operatorname{codes}^{\circ}$ for $^{\circ} \mathrm{Cex}$ with an endogenous secretory sequence that is cleaved upon $^{\circ}$ transport ${ }^{\circ}$ to ${ }^{\circ}$ the $e^{\circ}$ periplasm. ${ }^{\circ}$ The $^{\circ}$ plasmids $^{\circ}$ used, coding for Cex Asn44Ala, Gln87Met, and Gln87Tyr mutants, were all engineered based on the pUC121.1Cex(PTIS) plasmid. The plasmids were transformed into $E$. coli BL21 $(\lambda \mathrm{DE} 3)$ cells and cultured on agar media containing ampicillin with the resultant colonies selected for growth in liquid LB media and stored at $-80^{\circ} \mathrm{C}$. Wild-type Cex and its mutants were identically produced starting with a $20 \mathrm{~mL}$ overnight culture in a synthetic ${ }^{\circ}$ medium ${ }^{\circ}[23]^{\circ}$ containing ${ }^{\circ}$ ampicillin. ${ }^{\circ} \mathrm{A}^{\circ} 10^{\circ} \mathrm{mL}$ sample of the resultant culture was used to inoculate 1 $\mathrm{L}$ of synthetic medium, grown to an OD600 of $\sim 0.5$, induced with $0.1 \mathrm{mM}$ IPTG, and harvested $48 \mathrm{~h}$ after induction. The temperature was $30^{\circ} \mathrm{C}$ throughout the entire growth and expression period.
The cells were harvested by centrifugation (6000 $\mathrm{rpm}, 20 \mathrm{~min}$ ), resuspended in $\sim 25 \mathrm{~mL}$ of $50 \mathrm{mM}$ potassium phosphate, $0.02 \% \mathrm{NaN}_{3}$ at $\mathrm{pH} 7.2$ in $\mathrm{H}_{2} \mathrm{O}$ (K-P-7 buffer), and lysed by passage twice through a French-press cell at 10,000 psi. After addition of Complete protease inhibitor cocktail (Roche, Mannheim, Germany), cell debris was removed by centrifugation $(15,000 \mathrm{rpm}, 30 \mathrm{~min})$, and the supernatant, along with the original media supernatant, were stirred overnight at $4{ }^{\circ} \mathrm{C}$ with $\sim 20 \mathrm{~g}$ of degassed long fibrous cellulose (Sigma, St. Louis, MO) suspended in K-P-7 buffer. The cellulose was packed into a $\sim 150 \mathrm{~mL}$ FPLC column, washed with $\sim 270 \mathrm{~mL}$ of $1 \mathrm{M} \mathrm{NaCl}$ in K-P-7 buffer, and followed by $\sim 200 \mathrm{~mL}$ of K-P-7 buffer. The protein was eluted with $\mathrm{H}_{2} \mathrm{O}$ at $1 \mathrm{~mL} / \mathrm{min}$ while collecting $10 \mathrm{~mL}$ fractions. The appropriate fractions were pooled and concentrated to $\sim 10 \mathrm{~mL}$ using a $10 \mathrm{kDa}$ MWCO stirred ultrafiltration cell (Amicon Corp., Danvers, MA), and exchanged into a buffer containing $20 \mathrm{mM}$ sodium phosphate, $10 \mathrm{mM}$ EDTA, and $20 \mathrm{mM}$ cysteine hydrochloride at $\mathrm{pH}$ 7. Washed agarose-immobilized papain $(150 \mu \mathrm{L})$ (Pierce, Rockford, IL) was then added to cleave Cex at multiple sites within the linker region between its catalytic and cellulose binding domains. After incubation overnight at $37^{\circ} \mathrm{C}$ on a tube roller, the papain was removed by centrifugation at $5000 \mathrm{rpm}$. The agarose beads were rinsed three times with K-P-7 buffer, and all the supernatants were combined and incubated overnight at $4{ }^{\circ} \mathrm{C}$ on a tube roller with $2 \mathrm{~g}$ of washed avicel (Fluka Biochemika, Steinheim, Switzerland). The Avicel, with bound uncleaved Cex and the isolated cellulose binding domain, was removed by centrifugation at $5000 \mathrm{rpm}$. The supernatant, containing the catalytic domain of Cex, was concentrated by ultrafiltration using a $3 \mathrm{kDa}$ MWCO membrane and exchanged into $20 \mathrm{mM}$ potassium phosphate (K-P-8) buffer ( $\mathrm{pH} 8$ ), loaded onto a Hi-Trap Q HP column (GE Healthcare, Piscataway, NJ), and washed with $10 \mathrm{~mL}$ of $20 \mathrm{mM}$ K-P-8 buffer (pH8). The various mutants were eluted from the column using the above washing buffer supplemented with $1.0 \mathrm{M} \mathrm{NaCl}$ at a flow rate of 0.5 $\mathrm{mL} / \mathrm{min}$. Proteins can be detected from $0.6 \mathrm{M}$ to $1.0 \mathrm{M}$ $\mathrm{NaCl}$, and the appropriate fractions were collected, buffer-exchanged into distilled $\mathrm{H}_{2} \mathrm{O}$, and concentrated to a final volume of $\sim 1 \mathrm{~mL}$. The final enzyme concentrations were determined spectrophotometrically using a predicted value of $\varepsilon_{280^{\circ} \mathrm{nm}^{\circ}}={ }^{\circ} 52,870^{\circ} \mathrm{M}^{-1} \mathrm{~cm}^{-1^{\circ}}[36]$.

\section{References}

1. Covey, T. R.; Bonner, R. F.; Shushan, B. I.; Henion, J. The Determination of Protein, Oligonucleotide, and Peptide Molecular Weights by IonSpray Mass Spectrometry. Rapid Commun. Mass Spectrom. 1988, 2, 249-256.

2. Edmonds, C. G.; Loo, J. A.; Barinaga, C. J.; Udseth, H. R.; Smith, R. D. Capillary Electrophoresis Electrospray Ionization Mass Spectrometry. J. Chromatogr. 1989, 474, 21-37.

3. Ganem, B.; Li, Y. T.; Henion, J. D. Detection of Noncovalent ReceptorLigand Complexes by Mass Spectrometry. J. Am. Chem. Soc. 1991, 113, 6294-6296.

4. Loo, J. A. Studying Noncovalent Protein Complexes by Electrospray Ionization Mass Spectrometry. Mass Spectrom. Rev. 1997, 16, 1-23. 
5. Pramanik, B. N.; Bartner, P. L.; Mirza, U. A.; Liu, Y. H.; Ganguly, A. K. Electrospray Ionization Mass Spectrometry for the Study of Noncovalent Complexes: An Emerging Technology. J. Mass Spectrom. 1998, 33, 911-920.

6. Hoaglund-Hyzer, C. S.; Counterman, A. E.; Clemmer, D. E. Anhydrous Protein Ions. Chem. Rev. 1999, 99, 3037-3099.

7. Kitova, E.; Bundle, D. R.; Klassen, J. S. Thermal Dissociation of ProteinOligosaccharide Complexes in the Gas Phase: Mapping the Intrinsic Intermolecular Interactions. J. Am. Chem. Soc. 2002, 124, 5902-5913.

8. Hunter, C. L.; Mauk, A. G.; Douglas, D. J. Dissociation of Heme from Myoglobin and Cytochrome $b_{5}$ : Comparison of Behavior in Solution and the Gas Phase. Biochemistry 1997, 36, 1018-1025.

9. Schnier, P. D.; Klassen, J. S.; Strittmatter, E. F.; Williams E. R. Activation Energies for Dissociation of Double Strand Oligonucleotide Anions: Evidence for Watson-Crick Pairing in Vacuo. J. Am. Chem. Soc. 1998, 120, 9605-9613.

10. Wan, K. X.; Gross, M. L.; Shibue, T. Gas-Phase Stability of Double Stranded Oligodeoxynucleotides and Their Noncovalent Complexes With DNA-Binding Drugs as Revealed by Collisional Activation in an Ion Trap. J. Am. Soc. Mass Spectrom. 2000, 11, 450-457.

11. Potier, N.; Barth, P.; Tritsch, D.; Biellmann, J.-F.; Van Dorsselaer, A. Study of Noncovalent Enzyme-Inhibitor Complexes of Aldose Reductase by Electrospray Mass Spectrometry. Eur. J. Biochem. 1997, 243, $274-282$.

12. Jørgensen, T. J. D.; Delforge, D.; Remacle, J.; Bojensen, G.; Roepstorff, P. Collision-Induced Dissociation of Noncovalent Complexes between Vancomycin Antibiotics and Peptide Ligand Stereoisomers: Evidence for Molecular Recognition in the Gas Phase. Int. J. Mass Spectrom. 1999, $188,63-85$.

13. van der Kerk-van Hoof, A.; Heck, A. J. R. Covalent and Noncovalent Dissociations of Gas-Phase Complexes of Avoparcin and Bacterial Receptor Mimicking Precursor Peptides Studied by Collisionally Activated Decomposition Mass Spectrometry. J. Mass Spectrom. 1999, 34, 813-819.

14. Gao, J.; Wu, Q.; Carbeck, J.; Lei, Q. P.; Smith, R. D.; Whitesides, G. M. Probing the Energetics of Dissociation of Carbonic Anhydrase-Ligand Complexes in the Gas Phase. Biophys. J. 1999, 76, 3253-3260.

15. Rostom, A.; Tame, J. R. H.; Ladbury, J. E.; Robinson, C. V. Specificity and Interactions of the Protein OppA: Partitioning Solvent Binding Effects Using Mass Spectrometry. J. Mol. Biol. 2000, 296, 269-279.

16. Kitova, E. N.; Wang, W.; Bundle, D. R.; Klassen, J. S. Retention of Bioactive Ligand Conformation in a Gaseous Protein Trisaccharide Complex. J. Am. Chem. Soc. 2002, 124, 13980-13981.

17. Kitova, E. N.; Bundle, D. R.; Klassen, J. S. Evidence for the Preservation of Specific Intermolecular Interactions in Gaseous Protein-Oligosaccharide Complexes. J. Am. Chem. Soc. 2002, 124, 9340-9341.

18. Williams, S. J.; Hoos, R.; Withers, S. G. Nanomolar Versus Millimolar Inhibition by Xylobiose-Derived Aza-Sugars: Significant Differences Between Two Structurally Distinct Xylanases. J. Am. Chem. Soc. 2000, 122, 2223-2235.

19. (a) Williams, S. J.; Notenboom, V.; Wicki, J.; Rose, D. R.; Withers, S. G. A New, Simple, High-Affinity Glycosidase Inhibitor: Analysis of Binding Through X-Ray Crystallography, Mutagenesis, and Kinetic Analysis. J. Am. Chem. Soc. 2000, 122, 4229-4230; (b) Wicki, J.; Withers, S. G., unpublished.

20. Notenboom, V.; Williams, S. J.; Hoos, R.; Withers, S. G.; Rose, D. R. Detailed Structural Analysis of Glycosidase/Inhibitor Interactions:
Complexes of Cex from Cellulomonas fimi with Xylobiose-Derived Aza-Sugars. Biochemistry 2000, 39, 11553-11563.

21. Notenboom, V.; Birsan, C.; Warren, R. A. J.; Withers, S. G.; Rose, D. R Exploring the Cellulose/Xylan Specificity of the $\beta-1,4-$ Glycanase Cex from Cellulomonas fimi through Crystallography and Mutation. Biochemistry 1998, 37, 4751-4758.

22. MacLeod, A. M.; Lindhorst, T.; Withers, S. G.; Warren, R. A. J. The Acid/Base Catalyst in the Exoglucanase/Xylanase from Cellulomonas fimi is Glutamic Acid 127: Evidence from Detailed Kinetic Studies of Mutants. Biochemistry 1994, 33, 6371-6376.

23. Muchmore, D. C.; McIntosh, L. P.; Russell, C. B.; Anderson, D. E.; Dahlquist, F. W. Expression and Nitrogen-15 Labeling of Proteins for Proton and Nitrogen-15 Nuclear Magnetic Resonance. Methods Enzymol. 1989, 177, 44-73.

24. (a) Kamatari, Y. O.; Ohji, S.; Konno, T.; Yasutaka, S.; Kunitsugu, S. Kataoka, M.; Akasaka, K. The compact and denatured conformations of apomyoglobin in the methanol-water solvent. Protein Sci. 1999, 8 , 873-882; (b) Babu, K. R.; Moradian, A.; Douglas, D. J. The MethanolInduced Conformational Transitions of $\beta$-Lactoglobulin, Cytochrome $c$, and Ubiquitin at Low pH: A Study by Electrospray Ionization Mass Spectrometry. I. Am. Soc. Mass Spectrom. 2001, 12, 317-328.

25. Mauk, M. R.; Mauk, A. G.; Chen, Y. L.; Douglas, D. J. Tandem Mass Spectrometry of Protein-Protein Complexes: Cytochrome $c$-Cytochrome $b_{5}$. J. Am. Soc. Mass Spectrom. 2002, 13, 59-71.

26. Chen, Y. L.; Collings, B. A.; Douglas, D. J. Collision Cross Sections of Myoglobin and Cytochrome $c$ Ions with Ne, Ar, and Kr. J. Am. Soc. Mass Spectrom. 1997, 8, 681-687.

27. Douglas, D. J.; French, J. B. Collisional Focusing Effects in Radio Frequency Quadrupoles. J. Am. Soc. Mass Spectrom. 1992, 3, 398-408.

28. White, A.; Withers, S. G.; Gilkes, N. R.; Rose, D. R. Crystal Structure of the Catalytic Domain of the $\beta-1,4$ Glycanase Cex from Cellulomanas fimi. Biochemistry 1994, 33, 12546-12552.

29. Woodward, J. In Topics in Enzyme and Fermentation Biotechnology, VIII; Wiseman A., Ed.; Ellis Horwood Limited: Chichester, England, 1984, p 17

30. Heck, A. J. R.; van den Heuvel, R. H. H. Investigation of Intact Protein Complexes by Mass Spectrometry. Mass Spectrom. Rev. 2004, 23, 368 389.

31. Wang, W.; Kitova, E. N.; Klassen, J. Bioactive Recognition Sites May Not Be Energetically Preferred in Protein-Carbohydrate Complexes in the Gas Phase. J. Am. Chem. Soc. 2003, 125, 13630-13631.

32. Collings, B. A.; Douglas, D. J. Conformation of Gas-Phase Myoglobin Ions. J. Am. Chem. Soc. 1996, 118, 4488-4489.

33. Poon, D. K. Y.; Schubert, M.; Ludwiczek, M. L.; Kwan, E. M.; Withers, S. G.; McIntosh, L. P., unpublished.

34. Badman, E. R.; Hoaglund-Hyzer, C. S.; Clemmer, D. E. Monitoring Structural Changes of a Protein in an Ion Trap over $\sim 10-200 \mathrm{~ms}$ : Unfolding Transitions in Cytochrome c Ions. Anal. Chem. 2001, 73, 6000-6007.

35. O'Neill, G. P.; Kilburn, D. G.; Warren, R. A.; Miller, R. C., Jr. Overproduction from a Cellulase Gene with a High Guanosine-plus-Cytosine Content in Escherichia coli. Appl. Environ. Microbiol. 1986, 52, 737-743.

36. (a) Gasteiger, E.; Hoogland, C.; Gattiker, A.; Duvaud, S.; Wilkins, M. R.; Appel, R. D.; Bairoch, A. Protein Identification and Analysis Tools. In The Proteomics Protocols Handbook; Walker, J. M., Ed.; Humana Press: Totowa, NJ, 2005; pp 571-607; (b) Pace, C. N.; Vajdos, F.; Fee, L.; Grimsley, G.; Gray, T. How to Measure and Predict the Molar Absorption Coefficient of a Protein. Protein Sci. 1995, 4, 2411-2423. 